\section{Home and away}

\section{Ashley Montagu}

The Story of a Marriage: The Letters of Bronislaw Malinowski and Elsie Masson. Volume 1: 1916-20. Volume 2: 1920-1935. Edited by Helena Wayne. Routledge: 1995. Pp. 196/261. Each volume $£ 40, \$ 65$ (hbk); £13.99, \$17.95 (pbk).

WE owe these remarkable letters between two remarkable people - Bronislaw Malinowski, the founder of social anthropology and modern field work, and his wife Elsie Masson - to the energy and persistence of their youngest daughter Helena. It was Helena who travelled to Mexico to find her father's papers, which had been taken there in 1946, and she has now arranged both the letters and the diary material with skill. Here for the first time we are introduced to the delightful and talented Elsie. Indeed, the letters display Malinowski as her admiring sensitive friend and devoted lover. Not that Malinowski, with his normal distribution of faults, was ever in any sense forbidding; but he was often away from Elsie after returning to England in April 1920. This separation, and the worry about the impending birth of their first child, at which he could not be pre-

Malinowski in the Trobriand Islands, from his The Sexual Life of Savages (1929).

sent, not to mention very limited funds, meant that some people might not have seen him at his best.

They arrived in England shortly after the First World War, "the war to end all wars", when homes were promised "fit for heroes to live in". But with many of the surviving war heroes standing in the gutter selling pencils or eking out an existence as pavement artists along with the tragic figures of the unemployed, it was clear that something was very wrong with the country. Nevertheless Elsie and Bronio faced the austerity of the postwar years with equanimity: they remained cheerful, encouraged and inspired each other and never faltered in their loyalty and love.

In those years, the general psychosis cast its shadow of depression and cynicism over everyone. The feeling was one of betrayal, of abandonment, as if one had been emptied of all that one had formerly believed to be the principles of civilized life. In reaction to the dismaying bitterness and helplessness was the artificial gaiety of the 1920s and 1930s. Thrust into the midst of this bittersweet environment, with its warm enthusiasm for the new sciences as well as the arts, music and literature, the young Malinowskis found themselves very much alive.

In 1922 Malinowski began teaching at the London School of Economics (LSE), where two years later he established the first department of anthropology in the United Kingdom. He became part of the Bloomsbury circle of writers, artists and intellectuals of which it was said that almost every couple was a triangle and practically everyone lived in squares. It was a time when a surprising number of bright young people frequented the dark unfathomed caves at LSE, when the devotion that existed between Malinowski and his wife seemed hardly credible.

During his 19 months of fieldwork studying the Trobriander islanders between 1914 and 1918, Malinowski kept a strictly personal diary, written in Polish

\section{IMAGE UNAVAILABLE FOR COPYRIGHT REASONS}

and never intended for anyone's eyes but his own. Nevertheless, 25 years after his death it was edited by his second wife and translated and published in 1967 as $A$ Diary in the Strict Sense of the Term. There is hardly a page where Malinowski does not write with deep feeling of "E. R. M.", his spiritually betrothed Elsie Rosaline Masson; long after their marriage in 1919, Malinowski wrote that she "had treasures to give and the miraculous power to absolve sins".

Malinowski was something of an icon to his anthropological colleagues, as well as to other social scientists. With publication of Pacific in 1922, his reputation was at once established as a major star in the constellation of anthropologists, a reputation continually reinforced by his many subsequent publications. His diary therefore came as something of a shock, revealing his preoccupation with sex, his references to the Trobriander islanders as "niggers", and his depressions, illnesses and pills. And the role of "Peck's bad boy" that he would now and then choose to play, his ornery sense of humour and his occasional hapless asperities did not sit well with some of his colhis magnificent Argonauts of the Western

leagues and students. His derisive manner would sometimes give offence, when in fact he was simply trying to be amusing. All of this gave a rather skewed view of Malinowski, and many were incapable of seeing him from any other angle. Yet the diary is probably one of the most scrupulously honest self-criticisms ever penned by a man of feeling, who with all his flaws was at once an intellectual, a scientist, an original thinker, a superb teacher and a delightful human being.

The best corrective to any ill-considered view of Malinowski the man are the letters between him and Elsie from 1916 to her early death from multiple sclerosis at the age of 45 in 1935. The Story of a Marriage is a unique love story, chronicling their meeting, courtship and marriage. With the spread of Malinowski's fame and his long absences from home, Elsie was 䂧 often left missing him badly. She never complained, for she $\sum$ understood that the hustlebustle of a life led as an itinerant sophist was necessary to Malinowski; but her poignant letters to him cry out with her ache for them to be together.

Malinowski was not insensitive to this. In a letter to her as early as May 1926, he wrote: "I know that there will be a long gap in my correspondence... and I feel very unhappy about it. I have also an access of strong feeling of homesickness, after you and the babies and feel I am being cheated out of so much in life by not being able to live more

with them. . I cannot go away again from you after having been at home for about six weeks only!" But he continued to go away for weeks and sometimes months at a time, doing research in Africa and the Americas. Elsie supported and encouraged him in all his wanderings, gently enabling him to perceive the folly of his occasional intemperateness. Her high intelligence and winsome character shined out from the beginning of their marriage and throughout the ten years of the progressively debilitating course of her illness.

The Story of a Marriage contains much of interest about friends, colleagues, students, notable scientists, Malinowski's academic activities and travels, and all the information necessary for an all-round assessment of the man and the scientist. It will be of great value to social anthropologists and their students, to historians of science and to future biographers. But equally important is the introduction it gives to Malinowksi's wife, a woman of extraordinary character and sensibility who deserves to be widely known.

Ashley Montagu is at 321 Cherry Hill Road, Princeton, New Jersey 08540, USA. 